\title{
KOMPETENSI GURU DALAM PENGEMBANGAN KETERAMPILAN MOTORIK KASAR ANAK USIA DINI BERDASARKAN KUALIFIKASI AKADEMIK
}

\author{
Widodo \\ e-mail: widowida2@gmail.com \\ Puslitjakdikbud, Balitbang-Kemendikbud \\ Gedung E lantai 19, Jalan Jenderal Sudirman Senayan-Jakarta
}

\begin{abstract}
Abstrak: Artikel ini bertujuan untuk mengetahui kompetensi guru PAUD dalam mengembangkan keterampilan motorik kasar anak usia dini berdasarkan kualifikasi akademik dan menemukan upaya peningkatannya. Penelitian yang termasuk penelitian kepustakaan dengan pendekatan deskriptif kualitatif ini dilaksanakan September 2016 sampai dengan Januari 2017. Data dikumpulkan melalui akses internet dan manual, diolah, dan dianalisis secara deskriptif kualitatif. Hasil penelitian menunjukkan kompetensi guru PAUD yang kualifikasi akademiknya S1 PAUD sudah memadai, meskipun terjadi perbedaan kualitas berdasarkan program studi. Kompetensi guru yang kualifikasi akademiknya S1 kependidikan lain yang relevan dan psikologi belum memadai dikarenakan bekal pengetahuan yang mereka peroleh juga masih kurang. Penelitian ini merekomendasikan merevisi peraturan dan ketentuan dalam bentuk Peraturan Pemerintah dan Peraturan Menteriyang terkait dengan penyelenggaraan pendidikan guru PAUD.
\end{abstract}

Kata-kata Kunci: kompetensi, program studi, motorik kasar, usia dini, kualifikasi akademik

\section{THE COMPETENCES OF TEACHERS IN THE DEVELOPMENT OF GROSS MOTOR SKILLS FOR EARLY CHILDHOOD BASED ON ACADEMIC QUALIFICATIONS}

\begin{abstract}
This article aims to discover the competence of early childhood teachers in developing early gross motor skills based on academic qualifications and find out the improvement efforts. This library research iwith qualitative descriptive approach, was conducted as from September 2016 through January 2017. The data obtained from internet and other resources were processed and analyzed qualitatively. The results indicate that the competence of early childhood teachers whose academic qualification of early childhood education is adequate, although there are differences in quality based on the study program. The competence of teachers whose academic qualification of other relevant educational and psychological degrees is not sufficient because their provision of knowledge is also lacking. This research recommends to revise the existing regulations stated in the Government Regulations and Ministry Regulations related to the provision of the early childhood teachers.
\end{abstract}

Keywords: competence, study program, gross motor, early age, academic qualification

\section{PENDAHULUAN}

Pembangunan sektor kesehatan sangat mengharapkan keberhasilan upaya pengembangan kemampuan dan keterampilan motorik kasar anak usia dini, sebab anak yang keterampilan motorik kasarnya baik dapat terlibat lebih banyak dalam aktivitas fisik pada intensitas tinggi, sehingga terbebas dari penyakit kurang gerak yang dapat menimbulkan biaya tinggi untuk kesehatan. Hasil analisis terhadap data 142 negara, yang mewakili
93, 2 persen populasi dunia telah membuktikan, penduduk dunia telah menghabiskan dana sebesar \$ (INT \$) 53, 8 miliar untuk membiayai pengobatan penyakit kurang gerak pada tahun 2013 (Ding, D. et.al., 2016). Hasil analisis tersebut seiring dengan hasil tinjauan sistematis terhadap 39 penelitian dari tahun 1986 hingga 2007 yang melibatkan objek sebanyak 10.316 anak dari tujuh negara. Tinjauan sistematis tersebut telah membuktikan, 
hampir setengah jumlah anak prasekolah tidak mendapatkan aktivitas fisik yang cukup; hanya 54 persen anak yang melakukan aktivitas fisik selama 60 menit per hari sebagai persyaratan cukupnya suatu aktivitas fisik (Tucker, 2008). Mengenai pentingnya keterampilan motorik kasar bagi anak usia dini juga sudah dikaji ulang oleh Veldman SLC, et al. (2016) melalui review terhadap beberapa hasil penelitian yang telah dilakukan pada tahun sebelumnya (2007-2015); hasilnya membuktikan pentingnya pengembangan keterampilan motorik kasar dan perlunya perancangan program untuk meningkatkan keterampilan motorik kasar bagi anak usia dini

Pembangunan di bidang olahraga juga menanti keberhasilan dalam pengembangan keterampilan motorik kasar anak usia dini, sebab keberhasilan tersebut sangat diperlukan untuk membentuk atlet yang cerdas secara kinestetik, memiliki daya tahan, kekuatan, kelenturan, keterampilan, dan daya juang yang tinggi. Pernyataan ini sesuai dengan temuan Barati, H., et.al. (2012) bahwa posisi tubuh dan gerakan dasar yang baik dan benar seperti duduk, berdiri, berjalan, berlari dan gerakan lain dalam olah raga tidak dapat dicapai oleh anak jika program pengembangan motorik kasar yang benar tidak diterapkan; meskipun anak tersebut telah memiliki karakteristik sebagai anak yang energik dan dinamis. Dalam bidang olahraga, Cina merupakan salah satu negara yang meyakini benar bahwa pencapaian prestasi olahraga harus dimulai sejak usia dini, dan para akademisi Cina sepakat untuk memperkenalkan sepak bola sejak dini sebagai landasan dalam mewujudkan mimpi Cina bergabung ke dalam elit sepak bola dunia. Untuk itu para akademisi Cina telah melakukan langkah besar dengan memublikasikan buku untuk mewujudkan mimpi tersebut. Buku instruksional tentang dasar-dasar bermain sepak bola bagi anak TK yang terdiri atas tiga seri telah tersedia di seluruh wilayah di Cina. (Andal, C., 2016).

Pembangunan di bidang pendidikan secara umum juga membutuhkan keberhasilan pengembangan keterampilan motorik terutama motorik kasar. Hal ini dikarenakan adanya pengaruh keterampilan motorik terhadap perkembangan otak, yaitu pesatnya perkembangan otak turut menentukan kecerdasan anak. Terjadi hubungan timbal balik antara perkembangan kemampuan gerak dengan perkembangan fungsi otak; fungsi otak dapat berkembang secara baik ketika anak belajar gerak, dan sebaliknya ketika otak telah berkembang secara baik anak akan mampu melakukan gerak secara baik dan bahkan dapat digunakan untuk mengembangkan kemampuan-kemampuan lainnya seperti membaca, menulis dan sebagainya. Secara neurologi, aktivitas gerak dapat mengembangkan saraf sebagai jalur koneksi perjalanan informasi melalui otak dan anak yang jalur sarafnya lebih baik dapat belajar lebih mudah. Manfaat keterampilan motorik terhadap pendidikan, terutama dalam kesiapan akademik bagi anak juga telah terbukti secara ilmiah. Johnstone \& Ramon (2011) membuktikan, anak yang terpenuhi kebutuhannya dalam hal motorik kasar sebagai akibat berkembangnya persepsi motorik, kesiapan akademik dan perilaku mereka secara keseluruhan meningkat, dan bagi anak yang mengalami ketidakmampuan belajar dapat terbantu dalam mencapai potensinya secara penuh.

Satu hal yang lebih penting dari semua yang sudah dijelaskan di atas, adalah kepentingan individu anak. Program pengembangan motorik kasar perlu dilakukan dikarenakan kepentingan pertumbuhan dan perkembangan anak sebagai individu. Anak usia dini harus mendapat pengalaman gerak yang memadai terutama dalam keterampilan dan koordinasi motorik kasar sebagai unsur yang sangat mendasar bagi anak usia dini. Berkembangnya keterampilan dan koordinasi motorik kasar ini dapat menjadi penyubur berkembangnya unsur lain melalui aktivitas bermain seperti kecerdasan dan sosio-emosional, sebab anak usia dini yang memiliki keterampilan dan koordinasi motorik kasar yang baik dapat berperan lebih aktif dalam bermain. Hasil penelitian Sajedi dan Barati (2014) sangat mendukung pernyataan ini, sebab penelitiannya telah membuktikan bahwa pengalaman awal dalam bergerak akan membentuk dasar utama bagi pengembangan kemampuan persepsi-motorik, dan anak usia dini merupakan masa terbaik untuk meningkatkan kemampuan tersebut.

Dari uraian di atas dapat disimpulkan, program pengembangan keterampilan motorik bagi anak usia dini sangat penting untuk dilakukan sebab hasilnya sangat ditunggu dan terkait dengan pembanguan di bidang lainnya, antara lain bidang kesehatan, olahraga dan pendidikan, dan lebih lagi bagi individu anak.

Pendidikan anak usia dini (PAUD) bertujuan mengembangkan fungsi luhur kemanusiaan dan 
mempersiapkan anak agar memiliki "kesiapan belajar" (learning readiness). Kesiapan belajar merupakan persyaratan yang perlu dimiliki setiap anak usia dini agar dapat belajar di SD secara baik. Tidak terpenuhinya persyaratan tersebut dapat menyebabkan pencapaian hasil belajar di SD tidak dapat maksimal meskipun upaya yang dilakukan sudah optimal. Demikian juga halnya untuk belajar motorik kasar di SD, anak harus terlebih dahulu memiliki "kesiapan belajar motorik" pada tahap sebelumnya (Widodo, 2015). Pernyataan ini dikuatkan dengan pemberlakuan kurikulum 2013 (K13) yang sangat memerlukan kesiapan anak dalam proses pembelajarannya. K13 merujuk pada prinsip pembelajaran yang menuntut kemandirian anak untuk terlibat secara aktif, mencari tahu, dan belajar dari berbagai sumber belajar agar dapat merumuskan masalah dan menemukan alternatif pemecahan masalahnya. Guna mendapatkan perkembangan motorik kasar anak yang baik memerlukan upaya stimulasi. Hal ini telah dibuktikan oleh Permatasari (2011) bahwa keterampilan motorik kasar anak usia Toddler berkembang secara baik, ketika ibunya memberikan stimulasi yang memadai selama masa pengasuhan.

PAUD harus mampu mengantarkan anak usia dini mencapai standar tingkat pencapaian perkembangan anak (STPPA), termasuk di dalamnya perkembangan motorik kasar. Pengembangan keterampilan motorik kasar di PAUD harus mempersiapkan kesiapan anak untuk mencapai kompetensi dasar motorik kasar yang hendak dicapai di kelas $1 \mathrm{SD}$, yaitu kompetensi dasar yang ada dalam mata pelajaran Pendidikan Jasmani, Olahraga, dan Kesehatan (Penjasorkes) berdasarkan K13. Ketika anak memasuki kelas $1 \mathrm{SD}$, mereka akan belajar Penjasorkes yang lebih mengarah kepada pengembangan kemampuan dasar motorik kasar, yaitu mempraktikkan: (1) pola gerak dasar lokomotor, nonlokomotor, dan manipulatif; (2) aktivitas jasmani untuk keseimbangan dan kelincahan; (3) berbagai pola gerak dominan dalam senam; (4) pola gerak dasar senam sederhana yang dilandasi konsep gerak mengikuti irama; dan (5) berbagai bentuk permainan pengenalan air (Kemendikbud, 2013).

PAUD harus mampu memberikan pengalaman gerak yang memadai bagi setiap anak, sebab penelitian Dortaj dan Asemi (2012) telah membuktikan adanya efek dari program motorik dengan memilih keterampilan kognitif-motorik dan prestasi akademik pada siswa yang mengalami keterlambatan dalam belajar kognitif motorik. Mereka menemukan bahwa program yang telah disusun dan dicobakan memiliki efek positif pada perkembangan kemampuan kognitif-motorik termasuk keseimbangan dinamis dan statis, kecepatan, koordinasi, akurasi, kekuatan, dan peningkatan prestasi akademik. Lupu, E. (2010) juga telah meneliti pengaruh permainan motorik pada perkembangan mental dan motorik anak-anak prasekolah; dari 24 anak usia 5-6 tahun yang menjadi sampel dalam penelitiannya ditemukan perbedaan yang signifikan antara kelompok intervensi yang dilatih permainan motorik sepanjang minggu dengan kelompok kontrol yang hanya dilatih motorik sehari dalam seminggu. Analisis lebih lanjut terhadap hasil penelitiannya Lupu, E. (2011) menemukan bahwa penggunaan metode ilmiah dan sistematis dalam permainan memiliki efek positif pada penguasaan gerak dan peningkatan keterampilan motorik dan mental anak, dan dia menyimpulkan bahwa latihan motorik diperlukan untuk perkembangan motorik dan mental bagi anak prasekolah. Penelitian Pienaar et.al. (2011) juga membuktikan bahwa program pengembangan motorik memiliki dampak yang signifikan terhadap peningkatan anak usia dini dalam motorik halus, motorik kasar, perseptual-motor, dan sejumlah kemampuan motorik lainnya.

Dari uraian di atas dapat disimpulkan, PAUD mempunyai peran untuk mengantarkan anak usia dini mencapai kesiapan belajar motorik di sekolah dasar sesuai dengan K13, mencapai STTPA terutama dalam motorik kasar, dan memberikan pengalaman gerak yang memadai. Oleh karena itu, maka PAUD harus melakukan program pengembangan motorik bagi peserta didiknya.

Setelah melihat pentingnya perkembangan motorik kasar anak usia dini dan perlunya upaya pengembangan yang harus dilakukan oleh lembaga, maka para Guru PAUD sebagai sumber daya manusia di lembaga PAUD harus mampu merancang dan mengimplementasikan program pengembangan keterampilan motorik kasar bagi peserta didiknya. Kemampuan merancang dan mengimplentasikan program tersebut harus diawali dengan pembekalan yang baik dan bekal pengetahuan yang cukup. Oleh karena itu, pemberian bekal pengetahuan ketika para guru PAUD masih menjadi mahasiswa perlu mendapat perhatian yang serius; sebab kurangnya bekal pengetahuan dapat menyebabkan rendahnya kemampuan dan kompetensi guru PAUD. 
Guru PAUD dituntut untuk menguasai bidang garapan motorik kasar yang sangat luas; ada tiga kelompok besar gerak fundamental yang harus dikuasai, yaitu gerak lokomotor, non lokomotor, dan manipulasi. Mereka harus mampu memperagakan teknik gerak yang benar sesuai dengan ketentuan di dalam kinesiologi (ilmu gerak), dan memilih serta menerapkan metode dan strategi pembelajaran gerak yang tepat. Arah dari tuntutan atau kemampuan tersebut adalah agar anak usia dini benar-benar mendapat pelayanan optimal dalam mencapai STPPA dan kesiapan belajar motorik serta kesiapan belajar secara umum di sekolah dasar.

Terdapat satu fakta yang perlu dikaji lebih lanjut tentang guru PAUD dalam kaitannya dengan pengembangan keterampilan motorik kasar, yaitu syarat kualifikasi. Permendikbud Nomor 137 Tahun 2014 Pasal 25, ayat (1) butir b mengatur bahwa kualifikasi akademik guru PAUD memiliki ijazah diploma empat (D-IV) atau sarjana (S1) kependidikan lain yang relevan atau psikologi. Syarat kuaifikasi ini menyebabkan semakin luasnya varian kemampuan atau kompetensi guru PAUD dalam pengembangan keterampilan motorik kasar; bagi guru PAUD yang berlatar belakang pendidikan S1 PAUD barangkali tidak terlalu bermasalah karena memang mereka sudah dipersiapkan untuk menjadi guru PAUD, tetapi bagi guru PAUD yang berlatar belakang pendidikan S1 kependidikan lain yang relevan dan S1 psikologi perlu dipertanyakan kompetensi mereka, terutama dalam mengembangkan keterampilan motorik kasar.

Berdasarkan seluruh uraian di dalam latar belakang masalah dapat disimpulkan bahwa, (1) pengembangan keterampilan motorik kasar bagi anak usia dini sangat penting untuk dilakukan, terutama terkait dengan kepentingan perkembangan anak itu sendiri, dan secara umum terkait dengan manfaat keberhasilannya terhadap keberhasilan pembangunan dan pengembangan di bidang lainnya;
(2) PAUD harus mampu mengantarkan anak usia dini mencapai kesiapan belajar motorik di sekolah dasar sesuai dengan K13, mencapai STTPA dalam aspek motorik kasar, dan memberikan pengalaman gerak yang memadai; dan 3) guru PAUD sebagai unsur utama dalam penyelenggaraan PAUD harus memenuhi syarat kualifikasi akademik dan memiliki kompetensi yang memadai dalam pengembangan keterampilan motorik kasar anak usia dini.

Upaya pemenuhan kompetensi guru PAUD dalam pengembangan keterampilan motorik kasar anak usia dini secara hipotetik terkendala oleh ketentuan tentang syarat kualifikasi akademik sebab dengan adanya ketentuan bahwa sarjana kependidikan lain yang relevan dan sarjana psikologi diperbolehkan menjadi guru PAUD, pemenuhan kompetensi tersebut menjadi sulit tercapai. Hal ini sangat mungkin terjadi, karena sarjana kependidikan lain yang relevan dan sarjana psikologi tidak dipersiapkan untuk menjadi guru PAUD.

Permasalahan pemenuhan kompetensi terkait dengan syarat kualifikasi akademik di atas masih bersifat hipotetik, dan untuk kebenarannya perlu dibuktikan melalui kajian ini. Oleh karena itu, masalah dalam kajian ini dirumuskan: (1) Apakah guru PAUD yang berijazah S1 PAUD, S1 pendidikan lain yang relevan, dan $\mathrm{S} 1$ psikologi memiliki kompetensi yang sama dalam mengembangkan keterampilan motorik kasar anak usia dini? (2) Upaya apa yang harus dilakukan agar guru PAUD memiliki kompetensi yang memadai dalam pengembangan keterampilan motorik kasar anak usia dini?

Penelitian ini bertujuan untuk: (1) mengetahui kompetensi guru PAUD dalam mengembangkan keterampilan motorik kasar anak usia dini berdasarkan kualifikasi akademik; dan (2) menemukan upaya peningkatan kompetensi guru PAUD dalam pengembangan keterampilan motorik kasar anak usia dini.

\section{METODE PENELITIAN}

Penelitian ini menggunakan pendekatan deskriptif kualitatif dan merupakan jenis penelitian kepustakaan (library research) yaitu mengkaji berbagai pustaka yang terkait dengan kualifikasi dan kompetensi guru PAUD dalam pengembangan keterampilan motorik kasar anak usia dini. Ada empat jenis pustaka sebagai sumber data untuk memecahkan masalah penelitian, yaitu (1) struktur kurikulum program studi S1 PAUD, S1 kependidikan lain yang relevan, dan S1 psikologi; (2) peraturan pemerintah Indonesia yang terkait dengan penyelenggaraan pendidikan anak usia dini; (3) data tentang guru PAUD di Indonesia; dan (4) hasil penelitian dan kajian yang terkait pengembangan keterampilan motorik kasar anak usia dini. 
Teknik pengumpulan data dilakukan melalui akses internet dan koleksi dokumen secara manual. Data primer yang dikumpulkan dalam kajian ini adalah dokumen yang berisi struktur kurikulum program studi S1 PAUD, S1 pendidikan lain yang relevan, dan S1 psikologi dari beberapa perguruan tinggi penyelenggara program tersebut, dan peraturan perundang-undangan negara Republik Indonesia yang terkait dengan pengelolaan dan penyelenggaraan PAUD. Data skunder yang dikumpulkan adalah karya tulis ilmiah dalam bentuk hasil penelitian maupun kajian dari beberapa jurnal ilmiah baik dari dalam maupun luar negeri.

Untuk mengetahui kompetensi guru PAUD dalam mengembangkan keterampilan motorik kasar anak usia dini dilakukan pengolahan dan analisis terhadap jenis dan bobot mata kuliah yang terkait dengan pengembangan keterampilan motorik kasar anak usia dini yang ada di dalam struktur kurikulum program studi S1 PAUD, S1 pendidikan lain yang relevan, dan S1 psikologi. Hasil analisis ini dapat menggambarkan bekal pengetahuan dan kompetensi guru PAUD dalam pengembangan keterampilan motorik kasar anak usia dini. Teknik analisis ini mirip dengan studi yang dilakukan oleh Petrovici C. dan Masari, A.G. (2014a) dalam menggambarkan proses pembentukan tingkat kompetensi pada Fakultas Psikologi dan IImu Pendidikan, Universitas Alexandru Ioan Cuza Iasi. Dalam studi tersebut dilakukan korelasi antara kompetensi profesional dan transversal dengan isi kurikulum, subjek penelitian dan satuan kredit smester (SKS) yang dialokasikan dalam pendidikan major untuk Sekolah Dasar dan Prasekolah. Data pustaka berupa peraturan Pemerintah Republik Indonesia terkait dengan penyelenggaraan PAUD dan hasil-hasil penelitian diolah dan dianalisis secara kualitatif untuk memperkuat hasil penelitian.

\section{HASIL DAN PEMBAHASAN}

\section{Kompetensi Guru PAUD dalam Pengembangan Keterampilan Motorik Kasar Berdasarkan Kualifikasi Akademik}

Sebagaimana telah dijelaskan di dalam metode penelitian, kompetensi guru PAUD dalam pengembangan keterampilan motorik kasar didasarkan pada bekal pengetahuan yang diperoleh sebelumnya. Berdasarkan peraturan yang berlaku, tingkat pendidikan dapat menggambarkan kualifikasi akademik seorang guru PAUD di Indonesia. Lampiran II Permendikbud No. 137 Tahun 2014 tentang Standar Pendidikan Anak Usia Dini menjelaskan bahwa pendidik anak usia dini terdiri atas guru: PAUD, pendamping, dan pendamping muda. Syarat kualifikasi akademik khusus untuk guru PAUD antara lain (1) memiliki ijazah Diploma empat (D-IV) atau Sarjana (S1) dalam bidang pendidikan anak usia dini yang diperoleh dari program studi terakreditasi atau (2) memiliki ijazah diploma empat (D-IV) atau sarjana (S1) kependidikan lain yang relevan atau psikologi yang diperoleh dari program studi terakreditasi dan memiliki sertifikat pendidikan profesi guru (PPG) PAUD dari perguruan tinggi yang terakreditasi. Berdasarkan ketentuan tentang guru PAUD dan metode yang digunakan untuk mengetahui tingkat kompetensi tersebut, maka di dalam hasil dan pembahasan ini dipaparkan tentang kompetensi guru PAUD berdasarkan bekal pengetahuannya tentang pengembangan keterampilan motorik kasar sesuai dengan latar belakang pendidikannya.

\section{Kompetensi Guru PAUD dengan Kualifikasi Akademik S1 PAUD}

Guru PAUD yang berlatar belakang pendidikan S1 PAUD mendapatkan bekal pengetahuan tentang pengembangan keterampilan motorik kasar anak usia dini ketika masih menjadi mahasiswa pada program studi S1 PAUD. Pemberian bekal tersebut dilakukan melalui pembelajaran beberapa mata kuliah, antara lain pendidikan jasmani, bermain dan permainan, pengembangan motorik anak usia dini, dan pendidikan seni tari. Pendidikan seni tari di dalam penelitian ini dimasukkan ke dalam kelompok mata kuliah pengembangan motorik kasar, sebab di dalam tarian tersebut banyak melibatkan motorik kasar. Puspitarini (2015) dalam penelitiannya telah membuktikan bahwa penerapan tari kupu-kupu dapat meningkatkan kemampuan fisik motorik kasar anak-anak PAUD Tunas Bangsa, dan penelitian Utami (2014) juga membuktikan bahwa senam imajinasi (tari) dapat meningkatan ketetampilan motoriik kasar anak usia dini. Di dalam Tabel disajikan mata kuliah dan bobotnya/SKS yang terkait dengan pengembangan keterampilan motorik kasar pada program studi S1 PAUD di berbagai lembaga pendidikan tenaga keguruan (LPTK). 
Tabel

Program Studi S1 PAUD dan Mata Kuliah yang Terkait dengan Pengembangan Motorik Kasar

\begin{tabular}{|c|c|c|c|}
\hline $\begin{array}{l}\text { Program } \\
\text { studi S1 } \\
\text { PAUD }\end{array}$ & $\begin{array}{l}\text { Mata kuliah yang ter- } \\
\text { kait dengan pengem- } \\
\text { bangan motorik }\end{array}$ & SKS & Sumber \\
\hline \multirow{3}{*}{$\begin{array}{l}\text { Universi- } \\
\text { tas Negeri } \\
\text { Semarang }\end{array}$} & $\begin{array}{l}\text { Pengembangan Ke- } \\
\text { mampuan Motorik }\end{array}$ & 2 & \multirow{3}{*}{$\begin{array}{l}\text { Unnes } 2016 . \\
\text { http://paud. } \\
\text { unnes.ac.id/ } \\
\text { index.php/ } \\
\text { kurikulum/ }\end{array}$} \\
\hline & $\begin{array}{l}\text { Pembelajaran Tari } \\
\text { AUD }\end{array}$ & 3 & \\
\hline & $\begin{array}{l}\text { Bermain dan Media } \\
\text { Permainan }\end{array}$ & 3 & \\
\hline \multirow[t]{3}{*}{$\begin{array}{l}\text { Universitas } \\
\text { Terbuka }\end{array}$} & $\begin{array}{l}\text { Metode Pengemban- } \\
\text { gan Fisik }\end{array}$ & 4 & \multirow{3}{*}{$\begin{array}{l}\text { Universitas } \\
\text { Terbuka, } \\
2015\end{array}$} \\
\hline & $\begin{array}{l}\text { Bermain dan Per- } \\
\text { mainan Anak }\end{array}$ & 4 & \\
\hline & $\begin{array}{l}\text { Keterampilan Musik } \\
\text { dan Tari }\end{array}$ & 4 & \\
\hline \multirow{5}{*}{$\begin{array}{l}\text { Universi- } \\
\text { tas Negeri } \\
\text { Jakarta }\end{array}$} & $\begin{array}{l}\text { Metodologi Pengem- } \\
\text { bangan Jasmani AUD }\end{array}$ & 3 & \multirow{5}{*}{$\begin{array}{l}\text { DocSlide. } \\
\text { http://doku- } \\
\text { men.tips/ } \\
\text { documents/ } \\
\text { company- } \\
\text { profile-dan- } \\
\text { kurikulum- } \\
\text { pg-paud }\end{array}$} \\
\hline & $\begin{array}{l}\text { Bermain dan Per- } \\
\text { mainan AUD }\end{array}$ & 3 & \\
\hline & $\begin{array}{l}\text { Pengembangan } \\
\text { Motorik Batita }\end{array}$ & 3 & \\
\hline & $\begin{array}{l}\text { Pengembangan Jas- } \\
\text { mani Prasekolah }\end{array}$ & 2 & \\
\hline & $\begin{array}{l}\text { Pembelajaran Jas- } \\
\text { mani SD Kelas Awal }\end{array}$ & 2 & \\
\hline \multirow{4}{*}{$\begin{array}{l}\text { Universitas } \\
\text { Muham- } \\
\text { madiyah } \\
\text { Ponorogo }\end{array}$} & $\begin{array}{l}\text { Pendidikan Jasmani } \\
\text { AUD }\end{array}$ & 2 & \multirow{4}{*}{$\begin{array}{l}\text { http://pg- } \\
\text { paud.umpo. } \\
\text { ac.id/index. } \\
\text { php/kuriku- } \\
\text { lum/ }\end{array}$} \\
\hline & $\begin{array}{l}\text { Metode Pengemban- } \\
\text { gan Motorik }\end{array}$ & 3 & \\
\hline & $\begin{array}{l}\text { Seni Musik Gerak } \\
\text { dan Lagu AUD }\end{array}$ & 3 & \\
\hline & Seni Tari & 2 & \\
\hline \multirow{10}{*}{$\begin{array}{l}\text { Universitas } \\
\text { Pendidikan } \\
\text { Indonesia }\end{array}$} & $\begin{array}{l}\text { Pengembangan Fisik } \\
\text { Motorik AUD }\end{array}$ & 2 & \multirow{10}{*}{$\begin{array}{l}\text { http:// } \\
\text { pg-paud.st- } \\
\text { kipsiliwangi. } \\
\text { ac.id/kuriku- } \\
\text { lum/ } \\
\text { http://kd-cibi- } \\
\text { ru.upi.edu/id/ } \\
\text { index.php/ }\end{array}$} \\
\hline & Pendidikan Olahraga & 2 & \\
\hline & $\begin{array}{l}\text { Bermain dan Per- } \\
\text { mainan AUD }\end{array}$ & 2 & \\
\hline & $\begin{array}{l}\text { Pendidikan Musik } \\
\text { Gerak dan Lagu AUD }\end{array}$ & 2 & \\
\hline & $\begin{array}{l}\text { Pendidikan Seni } \\
\text { Tari } 1\end{array}$ & 2 & \\
\hline & $\begin{array}{l}\text { Pendidikan Seni } \\
\text { Tari } 2\end{array}$ & 2 & \\
\hline & $\begin{array}{l}\text { Strategi Pengemban- } \\
\text { gan Fisik-Motorik }\end{array}$ & 3 & \\
\hline & $\begin{array}{l}\text { Pendidikan Jasmani } \\
\text { dan Olahraga }\end{array}$ & 3 & \\
\hline & $\begin{array}{l}\text { Pendidikan Seni Tari } \\
\text { untuk AUD }\end{array}$ & 3 & \\
\hline & Bermain & 3 & \\
\hline
\end{tabular}

Melihat struktur kurikulum yang terkait dengan pengembangan keterampilan motorik anak usia dini pada Tabel 1 dapat disimpulkan, para mahasiswa program studi S1 PAUD sebagai calon guru PAUD sudah cukup mendapatkan bekal pengetahuan tentang pengembangan motorik kasar dan ketika menjadi guru PAUD mereka telah siap untuk melakukan hal tersebut. Simpulan ini tentu saja masih bersifat sementara, sebab masih memerlukan penelaahan lebih lanjut. Simpulan sementara ini bisa jadi benar apabila praktik pembelajaran terhadap mata kuliah yang terkait dengan pengembangan kemampuan motorik anak usia dini dilakukan secara baik dan mengarah kepada peningkatan pengetahuan dan keterampilan secara bersama-sama. Perlu diingat, untuk dapat mengembangkan atau mengajarkan gerakan motorik kasar secara benar, guru dituntut untuk dapat mempraktikkan gerakan secara benar, karena guru harus memberikan contoh atau peragaan setiap gerak yang diajarkannya. Namun sebaliknya, bisa juga simpulan sementara tersebut menjadi salah apabila praktik pembelajarannya tidak dilakukan secara baik atau hanya sekedar mengetahui secara teori dan kurang dalam peragaan dan praktik gerak.

Di dalam Deskripsi Umum dan Learning Outcome yang merupakan hasil deskripsi dari 12 sampel program studi LPTK di Indonesia dijelaskan sesuai Kerangka Kualifikasi Nasional Indonesia (KKNI), di dalam program studi S1 PAUD terdapat mata kuliah yang terkait dengan pengembangan kemampuan motorik, yaitu Strategi Pengembangan Fisik-Motorik dan Pendidikan Seni Tari untuk AUD yang bobotnya masing-masing 3 SKS. Di dalam deskripsi umum tersebut juga ditemukan silabus program studi S1 PG-PAUD yang di dalamnya terdapat pokok bahasan keterampilan meningkatkan keterampilan fisik anak usia dini dengan indikator ketercapaian kompetensinya antara lain (1) mahasiswa menguasai konsep tentang meningkatkan keterampilan fisik anak usia dini melalui kegiatan: berlari, melompat, berjalan, merangkak; dan (2) mahasiswa mampu mensimulasikan keterampilan meningkatkan keterampilan fisik anak usai dini. Kegiatan Perkuliahan untuk mencapai indikator tersebut dilakukan dengan cara: mahasiswa mempresentasikan materi tentang keterampilan meningkatkan keterampilan fisik anak usia dini dan dilanjutkan dengan simulasi (Kemendikbud, 2013). Informasi ini lebih menguatkan lagi bahwa mahasiswa lulusan program S1 PAUD telah mendapatkan bekal yang cukup dalam pengembangan keterampilan motorik kasar anak usia dini.

Berdasarkan data Tabel, sebenarnya 
terdapat masalah yang harus dipecahkan di balik ketercukupan bekal pengetahuan tentang pengembangan motorik kasar anak usia dini, yaitu bervariasinya jenis dan bobot SKS setiap mata kuliah antar LPTK. Variasi ini dapat menyebabkan tidak meratanya kompetensi atau kualitas lulusan antar LPTK. Guru PAUD yang sebelumnya belajar di LPTK yang memberikan materi pengembangan motorik secara lengkap dan bobot SKSnya lebih tinggi akan memiliki kompetensi yang lebih baik dalam pengembangan motorik anak usia dini. Dampak variasi ini adalah tidak meratanya kualitas pengembangan keterampilan motorik kasar anak usia dini antarlembaga PAUD. Bagi lembaga PAUD yang gurunya berasal dari LPTK dengan pemberian bekal pengetahuan tentang pengembangan motoriknya cukup lengkap dan berbobot, proses pengembangan keterampilan motorik kasarnya akan lebih baik. Tidak meratanya pemberian bekal pengetahuan tentang pengembangan keterampilan motorik anak usia dini antarprogram studi S1 PAUD harus diperbaiki dengan melakukan revisi terhadap Peraturan Pemerintah Nomor 17 Tahun 2010 tentang Pengelolaan dan Penyelenggaraan Pendidikan. Pasal 97 ayat (2) di dalam Peraturan Pemerintah tersebut mengatur, kurikulum tingkat satuan pendidikan untuk setiap program studi di perguruan tinggi dikembangkan dan ditetapkan oleh tiap-tiap perguruan tinggi. Ketentuan inilah yang menyebabkan terjadinya perbedaan jenis dan bobot mata kuliah antar LPTK, terutama yang terkait dengan pengembangan keterampilan motorik kasar bagi anak usia dini. Untuk itu, perlu dilakukan revisi yang target utamanya agar struktur kurikulum yang terkait dengan pengembangan kemampuan motorik kasar anak usia dini berlaku sama bagi seluruh perguruan tinggi penyelenggara program studi S1 PAUD.

Muara ketentuan tentang kompetensi guru PAUD dalam pengembangan motorik kasar adalah guru mampu mengajar dan membimbing siswanya untuk mencapai standar tingkat pencapaian perkembangan anak (STPPA). Berdasarkan Permendikbud Nomor 137 Tahun 2014 tentang Standar Nasional Pendidikan Anak Usia Dini, STPPA bagi peserta didik usia 5-6 tahun pada aspek motorik kasar antara lain (1) melakukan gerakan tubuh secara terkoordinasi untuk melatih kelenturan, keseimbangan, dan kelincahan; (2) melakukan koordinasi gerakan mata-kaki-tangan-kepala dalam menirukan tarian atau senam; (3) melakukan permainan fisik dengan aturan; dan (4) terampil menggunakan tangan kanan dan kiri. STPPA inilah yang harus diupayakan oleh guru PAUD terhadap peserta didiknya yang akan memasuki SD. Setelah melihat struktur kurikulum dan silabus peningkatan keterampilan fisik anak usia dini, dapat disimpulkan, pembekalan yang dilakukan oleh program studi S1 PAUD kepada calon guru PAUD telah memadai, dan guru PAUD dengan kualifikasi akademik S1 PAUD sudah layak untuk membimbing siswa mencapai STPPA pada aspek motorik kasar usia 5-6 tahun. STPPA PAUD Indonesia tidak jauh berbeda dengan indikator keberhasilan pendidikan pra sekolah di New Jersey. Indikator keberhasilan untuk pengembangan motorik kasar dalam pendidikan prasekolah di New Jersey antara lain (1) adanya pengembangan dan perbaikan dalam keterampilan motorik kasar seperti meloncat, menderap, meloncat, berlari, dan berbaris; dan (2) adanya pengembangan dan perbaikan keterampilan dan koordinasi seperti melempar, menangkap bola, memutar gelang-gelang rotan di pinggul,dan berjalan di balok keseimbangan (New Jersey Department of Education,2014).

Dari seluruh uraian tentang kompetensi guru PAUD dengan kualifikasi akademik S1 PAUD dapat disimpulkan bahwa (1) guru PAUD dengan kualifikasi akademik S1 PAUD telah mendapatkan bekal pengetahuan yang cukup tentang pengembangan keterampilan motorik kasar anak usia dini dari program studi S1 PAUD; (2) perbedaan struktur kurikulum antar penyelenggara program studi S1 PAUD menyebabkan tidak meratanya kompetensi guru PAUD dalam pengembangan kemampuan motorik kasar anak usia dini; (3) perbedaan struktur kurikulum antar penyelenggara program studi S1 PAUD disebabkan oleh PP No. 17 Tahun 2010 yang membolehkan setiap penyelenggara program studi S1 PAUD untuk mengembangkan dan menetapkan kurikulum tingkat satuan pendidikan; dan (4) bekal pengetahuan yang cukup menjadikan guru PAUD dengan kualifikasi S1 PAUD layak untuk membimbing siswanya mencapai STPPA pada aspek motorik kasar.

Kompetensi Guru PAUD dengan Kualifikasi Akademik S1 Kependidikan Lain yang Relevan

Permendikbud Nomor 137 Tahun 2014 Pasal 25, ayat (1) butir b mengatur, kualifikasi akademik guru PAUD memiliki ijazah diploma empat (D-IV) atau sarjana (S1) kependidikan lain yang relevan 
atau psikologi. Pengertian "kependidikan lain yang relevan" ini terlalu luas dan menimbulkan penafsiran yang berbeda; penulis menafsirkan bahwa kependidikan lain yang relevan tersebut adalah pendidikan guru sekolah dasar (PGSD), bimbingan dan konseling (BK), pendidikan luar biasa (PLB), dan pendidikan luar sekolah (PLS).

Di dalam Deskripsi Umum dan Learning Outcome, dari 12 sampel program studi di LPTK tidak ditemukan adanya mata kuliah yang terkait dengan pengembangan kemampuan motorik kasar anak usia dini. Program studi S1 kependidikan lain yang dianggap relevan dengan program studi S1 PAUD, yaitu PGSD, BK, PLB, dan PLS juga tidak mengajarkan mata kuliah tersebut (Kemendikbud, 2013). Data ini membuktikan bahwa mahasiswa pada program studi S1 PGSD, BK, PLB, dan PLS yang dianggap sebagai program studi kependidikan lain yang relevan tidak mendapatkan bekal pengetahuan tentang pengembangan keterampilan motorik kasar bagi anak usia dini. Di dalam Deskripsi Umum dan Learning Outcome terdapat program studi S1 kependidikan yang memberikan mata kuliah terkait dengan pengembangan keterampilan motorik kasar secara masif, meskipun tidak secara spesifik mengarah kepada anak usia dini. Program studi tersebut adalah Pendidikan Jasmani Kesehatan dan Rekreasi (PJKR). Mahasiswa program studi S1 PJKR mendapatkan mata kuliah yang terkait dengan pengembangan keterampilan motorik secara lengkap, antara lain (1) pembelajaran berbagai cabang olahraga; (2) teori belajar motorik; (3) perkembangan motorik; (4) biomekanik; dan (5) pembalajaran aktivitas senam dan ritmik; dan masih banyak lagi yang lainnya (Kemendikbud, 2013).

Berdasarkan data di atas dapat disimpulkan, sarjana kependidikan selain sarjana PAUD tidak ada yang mendapatkan bekal pengetahuan yang cukup tentang pengembangan keterampilan motorik kasar bagi anak usia dini. Ada sarjana kependidikan di luar sarjana PAUD yang memiliki bekal pengetahuan yang cukup tentang pengembangan motorik kasar, meskipun tidak secara spesifik mengarah kepada anak usia dini, yaitu sarjana PJKR.

Terdapat peluang yang dapat dikembangkan untuk pemenuhan kompetensi guru PAUD dalam pengembangan motorik kasar anak usia dini bagi guru yang latar belakang pendidikan bukan sarjana PAUD. Peluang yang paling besar adalah menjadikan sarjana PJKR sebagai prioritas utama dalam pengertian "kependidikan lain yang relevan". Pertimbangan logisnya dapat dijelaskan sebagai berikut: para sarjana PJKR telah menempuh program studi S1 PJKR sehingga mereka telah mendapatkan bekal pengetahuan yang cukup dalam pengembangan keterampilan motorik kasar. Kekurangan yang ada pada mereka adalah kurang mendapatkan bekal tentang pengembangan motorik kasar bagi anak usia dini. Kekurangan ini lebih mudah diatasi sebab pada dasarnya mereka telah terseleksi memiliki bakat dan kemampuan dalam pembelajaran gerak dan motorik. Kondisi yang berlawanan akan terjadi jika pengertian "kependidikan lain yang relevan" tersebut dimaknai sebagai PGSD, BK, PLB dan PLS. Sarjana kependidikan jenis ini memerlukan upaya yang lebih besar untuk memiliki kompetensi dalam pengembangan keterampilan motorik kasar anak usia dini. Keberbakatan dalam gerak menjadi masalah terbesar dalam upaya mewujudkan kompetensi mereka karena pada awalnya mereka tidak berbakat dan berminat dalam belajar gerak, tentu akan menguras energi yang cukup besar untuk memiliki kompetensi dalam pengembangan keterampilan motorik kasar.

\section{Kompetensi Guru PAUD dengan Kualifikasi Akademik S1 Psikologi}

Guru PAUD yang berlatar belakang pendidikan S1 psikologi sudah mendapatkan bekal pengetahuan tentang perkembangan motorik anak usia dini, sebab mereka memperoleh mata kuliah Psikologi Perkembangan I dan Il yang masing-masing bobotnya 3 SKS. Psikologi Perkembangan I merupakan mata kuliah yang paling banyak membahas tentang perkembangan fisik dan motorik anak usia dini, sedangkan Psikologi Perkembangan II lebih fokus kepada remaja dan dewasa. Di dalam psikologi perkembangan dibahas mengenai prinsip-prinsip perkembangan, perkembangan fisik dan motorik, faktor yang memengaruhi perkembangan motorik, kerawanan dan cara pengembangan motorik, serta pengertian dan perkembangan bermain pada anak (Universitas Padjadjaran, 2012). Mahasiswa Program Studi S1 Psikologi Universitas Mercu Buana Yogyakarta mendapat pembekalan lebih lengkap, sebab mereka belajar tentang Rentang Perkembangan Manusia I dan II masing-masing 3 SKS, Deteksi Dini dalam Perkembangan, Seminar Psikologi Pendidikan Perkembangan, bahkan mendapatkan mata kuliah Metode Pembelajaran PAUD yang bobotnya masing-masing 2 SKS (http:// 
fpsi.mercubuana-yogya.ac.id/ Kurikulum.php, diunduh 12 November 2016).

Kolokium Psikologi Indonesia (2010) telah menetapkan kompetensi pendidikan bidang psikologi. Kolokium tersebut mencantumkan, lulusan pendidikan sarjana psikologi yang bergelar Sarjana Psikologi (S.Psi.) dapat bekerja sebagai pendidik di bidang pendidikan anak usia dini. Mahasiswa S1 psikologi mendapatkan mata kuliah Psikologi Perkembangan I dan II, masing-masing bobotnya 3 SKS. Materi yang terkait dengan perkembangan motorik anak usia dini diajarkan pada mata kuliah Psikologi Perkembangan I dengan tujuan pengajarannya antara lain (1) memahami ruang lingkup, konsep-konsep dasar, beberapa teori dan metodologi dalam psikologi perkembangan; (2) memahami tahap perkembangan pranatal, bayi, kanak-kanak dan anak serta karakteristik tiap tahap; (3) memahami perkembangan fisik dan aspek psikis tahap bayi sampai anak. Khusus untuk mata kuliah Psikologi Perkembangan I materi ajarnya meliputi (1) pengertian dan prinsip dasar perkembangan, periodisasi dalam perkembangan dan segala karakteristiknya; (2) sejarah psikologi perkembangan; (3) pelopor dan ruang lingkup psikologi perkembangan; (4) konsep dasar dalam psikologi perkembangan dan prinsip - prinsip perkembangan; (5) metode penelitian dalam psikologi perkembangan; (6) beberapa teori dalam psikologi perkembangan; (7) tahap perkembangan dan karakteristik tiap tahap (meliputi perkembangan fisik, sosial dan emosi, kognisi dan perkembangan bahasa); (8) pola asuh dan pengaruhnya terhadap perkembangan anak; dan (9) proses tumbuh kembang prenatal bayi sampai anak, baik dari sisi perkembangan fisik maupun psikologis.

Berdasarkan seluruh mata kuliah yang diajarkan pada Program Studi S1 Psikologi di atas dapat disimpulkan, secara umum sarjana psikologi layak untuk berperan serta dalam pembelajaran anak usia dini, namun masih perlu didiskusikan lebih lanjut untuk dapat memberikan pembelajaran tentang keterampilan motorik kasar. Masalah utama yang harus didiskusikan adalah terkait dengan didaktikmetodik di dalam pembelajaran gerak atau motorik, terutama pada aspek motorik kasar. Sebagai bahan perbandingan, lulusan Program Studi S1 PAUD yang telah dinyatakan memiliki kompetensi yang memadai dari hasil analisis kajian ini, mereka sudah diarahkan untuk menguasai konsep tentang meningkatkan keterampilan fisik anak usia dini melalui kegiatan: berlari, melompat, berjalan, dan merangkak. Selain itu, mereka juga harus mensimulasikan keterampilannya dalam meningkatkan keterampilan motorik kasar anak usia dini. Pengalaman belajar yang ditempuh oleh mahasiswa S1 PAUD ini tidak dialami oleh mahasiswa S1 psikologi, sehingga kompetensi sarjana psikologi dalam pengembangan keterampilan motorik anak usia dini tidak akan setinggi sarjana PAUD. Namun demikian, ketentuan khusus perlu diterapkan bagi sarjana psikologi yang secara intensif mendapatkan mata kuliah tentang pendidikan anak usia dini dan pengembangan motorik seperti yang dilakukan oleh Program Studi S1 Psikologi Universitas Mercu Buana Yogyakarta.

Sarjana psikologi secara umum kurang mendapatkan pengetahuan praktis dan praktik mengembangkan motorik kasar anak usia dini. Padahal, ketika menjadi guru PAUD mereka harus memiliki kompetensi seperti yang dijelaskan oleh Petrovici dan Masari. Menurut Petrovici dan Masari (2014b), kompetensi mengajar itu menyangkut pengetahuan, keterampilan, dan sikap; sehingga guru PAUD harus mengetahui apa yang diajarkan, bagaimana mengajarkannya, dan mempunyai alasan mengapa hal tersebut diajarkan. Yudanto (2007) juga menjelaskan, dalam belajar keterampilan motorik, anak usia dini harus dibimbing untuk melakukan gerakan sederhana sebelum menghubungkannya ke dalam gerakan yang lebih sulit atau menguasai suatu keterampilan gerak. Pemberian bimbingan dan contoh inilah yang sulit untuk dipenuhi guru PAUD yang kualifikasi akademiknya S1 psikologi, karena mereka tidak memiliki bekal praktik tentang hal tersebut. Sebagai bahan perbandingan, guru pra sekolah di New Jersey harus mampu: (1) memfasilitasi aktifitas yang secara khusus meningkatkan keterampilan gerak seperti: merangkak melalui terowongan, bergerak menyebar tanpa menyentuh benda dan teman-teman di sekitarnya, melompat dan mendarat dari ketinggian secara benar; (2) membimbing dan mendukung anak dalam mengembangkan keterampilan motorik kasar seperti: melakukan start lari, berhenti, berputar, jingkat, berbaris; dan (3) membuat perencanaan aktivitas untuk kelompok besar dan kecil, dan peralatan yang dapat meningkatkan keterampilan motorik kasar seperti gerak permainan, menari, bermain luar ruang, dan melempar ke drum sebagai sasaran (New Jersey 
Department of Education,2014).

Dari seluruh data dan informasi tentang bekal pengetahuan yang diperoleh sarjana psikologi ketika masih kuliah dapat disimpulkan, sarjana psikologi belum mendapatkan bekal pengetahuan yang cukup tentang mengembangan keterampilan motorik kasar anak usia dini, terutama pengetahuan praktis dan pengalaman praktik pengembangan. Namun demikian, mereka memperoleh pengetahuan teori yang cukup tentang pertumbuhan dan perkembangan motorik anak usia dini. Berdasarkan kondisi ini, guru PAUD yang kualifikasi akademiknya sarjana psikologi sebaiknya tidak berperan secara tunggal dalam pembelajaran di PAUD. la harus berkolaborasi dengan guru yang memiliki kompetensi dalam pengembangan keterampilan motorik kasar. Upaya Peningkatan Kompetensi Guru PAUD dalam Pengembangan Keterampilan Motorik Kasar Anak Usia Dini.

\section{Peningkatan kualifikasi akademik}

Upaya mengatasi masalah kompetensi guru sangat terkait dengan peningkatan kualifikasi akademik,semakin tinggi kualifikasi akademik guru semakin tinggi kompetensinya dalam pembelajaran. Pernyataan ini sesuai dengan temuan Sheridan (2009), kepentingan utama keberaadaan seorang staf atau guru PAUD terletak pada pengaruhnya terhadap kualitas proses dan kualitas pelayanan terhadap anak usia dini. Beberapa hasil penelitian telah membuktikan adanya pengaruh guru yang berkualitas terhadap proses pembelajaran. Pedagogi yang berkualitas tinggi untuk selanjutnya dapat mewujudkan hasil belajar yang lebih baik. Norris, (2010) juga telah membuktikan, guru anak usia dini yang tingkat kualifikasinya lebih tinggi cenderung terlibat dalam interaksi yang sesuai secara sensitif, responsif dan pro aktif. Penelitian Fitriya (2014) menjelaskan lebih spesifik,terdapat perbedaan kualitas mengajar antara guru TK tingkat pendidikan D-II PGTK dengan S1 PAUD dan S1 non PAUD; guru PAUD dengan latar belakang pendidikan S1 lebih tinggi dibandingkan dengan D-II PGTK.

Kualifikasi akademik yang dipersyaratkanbagi guru PAUD di Indonesia adalah Diploma IV atau S1. Ketentuan tersebut sudah tepat jika dibandingkan dengan beberapa negara lainnya. Negara lain pada umumnya menetapkan persyaratan, guru PAUD harus sudah menempuh pendidikan di perguruan tinggi selama 3 s.d 4 tahun. Untuk menjadi guru pra sekolah di Inggris perlu belajar di perguruan tinggi selama empat tahun, di Swedia tiga setengah tahun, di Denmark tiga sampai lima tahun kejuruan atau pendidikan tinggi, tergantung pada pengalaman sebelumnya, dan di Amerika Serikat mensyaratkan kursus pengasuhan satu tahun hingga belajar di Perguruan Tinggi selama empat tahun untuk menjadi guru pada sekolah negeri termasuk pada Pengasuhan Anak (Department for Education, England, 2013). Berdasarkan perbandingan ini, pemenuhan kualifikasi akademik setara Diploma IV atau S1 bagi guru PAUD di Indonesia perlu dilakukan agar guru PAUD di Indonesia sejajar dengan negara lainnya.

Tingkat pendidikan sebagian besar guru PAUD di Indonesia pada tahun 2013/2014 belum mencapai sarjana (S1). Guru Taman Kanak-kanak (TK) yang tingkat pendidikannya S1 baru mencapai 40,17 persen, dan pendidik PAUD nonformal hanya 21,4 persen ditambah dengan $\mathrm{S} 2$ ke atas 0,67 persen. Secara keseluruhan guru PAUD masih didominasi oleh guru yang belum sarjana; berijazah Diploma sebanyak 9,69 persen, guru pengasuh dan pengasuh muda dengan tingkat pendidikan SMA 61,9 persen, dan SMP 6,34 persen (Kemdikbud, PDSP. 2014).

Kualifikasi guru seperti data di atas perlu ditingkatkan mengingat pentingnya peningkatan kualifikasi terhadap kualitas pembelajaran. Upaya peningkatan yang dilakukan harus masuk ke dalam program peningkatan kualifikasi dan kompetensi dalam jabatan, karena data di atas adalah data guru yang sudah menjadi guru di lembaga PAUD. Peningkatan kualifikasi dan kompetensi dalam jabatan berati mewajibkan guru PAUD menempuh pendidikan program S1 PAUD bagi guru yang belum memiliki ijazah S1. Upaya peningkatan dalam bentuk mewajibkan seperti ini perlu mempertimbangkan status kepegawaian guru PAUD karena masih banyak guru PAUD yang berstatus sebagai guru honorer. Data dari PDSP menunjukkan bahwa 41,05 persen atau 154.812 guru berstatus sebagai guru tidak tetap (Kemdikbud, PDSP. 2014). Dalam statusnya sebagai guru tidak tetap, honor yang pendapatannya tidak memungkinkan untuk membiayai pendidikannya ke jenjang S1 PG-PAUD. Untuk itu, pemerintah Indonesia harus menanggung biaya yang jumlahnya sangat besar, sebab sampai dengan tahun 2014 masih ada 180.791 guru TK (59,83 persen) yang belum memiliki ijazah S1 (Kemdikbud, PDSP. 2014). 
Peningkatan kualifikasi yang dikaji di dalam penelitian ini adalah peningkatan kualifikasi yang lebih menekankan kepada tercapainya kompetensi guru PAUD di bidang pengembangan keterampilan motorik kasar anak usia dini. Dengan penekanan tersebut, kewajiban menempuh pendidikan S1 bagi semua guru yang belum berkualifikasi sarjana harus mengarah kepada tercapainya kompetensi di bidang pengembangan keterampilan motorik. Sebenarnya, kalau mengacu pada peraturan yang berlaku, untuk meningkatkan kualifikasinya para PAUD dapat melanjutkan studinya pada program studi S1 psikologi atau S1 kependidikan lainnya. Namun demikian, setelah melihat data bahwa hanya sarjana PAUD yang memperoleh bekal pengetahuan yang cukup tentang pengembangan keterampilan motorik anak usia dini maka hanya program studi S1 PAUD yang sesuai bagi guru PAUD.

Ada satu hal yang menarik dalam peningkatan kualifikasi guru PAUD terkait dengan pengembangan keterampilan motorik kasar, yaitu ketentuan mengenai kualifikasi akademik "S1 kependidikan lain yang relevan". Ketika sarjana S1 kependidikan lain yang relevan (seperti PGSD, BK, PLB, dan PLS) tidak memenuhi kompetensi di bidang pengembangan keterampilan motorik kasar anak usia dini, dan memerlukan upaya yang sangat besar untuk meningkatkan kompetensinya maka akan lebih baik jika pengertian "kependidikan lain yang relevan" di dalam Permendikbud Nomor 137 Pasal 25, ayat (1) butir b adalah S1 PJKR. Pada Program Studi S1 PJKR diajarkan mata kuliah yang terkait dengan pengembangan motorik kasar secara cukup dan lengkap, sehingga para lulusannya sangat memadai dalam pengembangan keterampilan motorik kasar anak usia dini. Namun, hal ini tidak sepenuhnya benar, sebab sarjana PJKR dirancang untuk mengajar pada jenjang pendidikan menengah, sehingga akan sedikit kesulitan ketika harus mengajar anak usia dini. Guna mengatasi hal ini dapat dilakukan dua hal, yaitu: (1) pelatihan tentang pembelajaran anak usia dini bagi para guru PAUD dengan kualifikasi S1 PJKR; dan/atau (2) penambahan mata kuliah tentang pembelajaran anak usia dini pada Program Studi S1 PJKR, agar lulusan program S1 PJKR layak untuk menjadi guru PAUD.

Dari uraian di atas dapat disimpulkan, untuk mengatasi permasalahan kualifikasi akademik guru PAUD sekaligus memiliki kompetensi yang memadai di bidang pengembangan keterampilan motorik kasar anak usia dini maka perlu dilakukan tiga hal: (1) pemberian beasiswa pendidikan S1 PAUD oleh pemerintah Indonesia kepada guru PAUD yang belum memiliki kualifikasi akademik $S 1,\{2)$ menjadikan S1 PJKR sebagai salah satu syarat kualifikasi akademik untuk menjadi guru PAUD, dan (3) menambahkan mata kuliah pengembangan motorik bagi anak usia dini pada Program Studi S1 PJKR.

\section{Peningkatan kompetensi}

Setelah melihat data bahwa masih banyak guru PAUD yang belum sarjana, dibolehkannya sarjana kependidikan lain dan psikologi sebagai syarat menjadi guru PAUD, dan tidak meratanya jumlah dan kualitas pemberian bekal pengetahuan tentang pengembangan motorik antar program studi S1 PAUD maka dapat disimpulkan bahwa kompetensi guru PAUD dalam pengembangan keterampilan motorik anak usia dini masih rendah. Hasil penelitian Marlina (2011) di DKI Jakarta mendukung kesimpulan ini. Dia juga menyimpulkan, kemampuan guru TK dalam mengajar gerak masih rendah yaitu hanya 30 persen guru memiliki kemampuan tinggi, 27 persen sedang, dan 43 persen rendah. Guru yang menguasai berbagai macam gerakan 10,2 persen, guru dengan kreativitas baik dalam dalam pengayaan gerakan 16,7 persen, dan guru yang memiliki kemampuan fisik secara baik 14,4 persen. Penelitian sejenis juga dilakukan oleh Mariyana (2012) dan hasilnya membuktikan, guru TK yang memiliki kompetensi di lapangan secara keseluruhan sebesar 29,80 persen, kompetensi kepribadian 24,61 persen, dan kompetensi sosial 22,29 persen.

Kompetensi guru PAUD yang masih kurang dalam pengembangan keterampilan motorik anak usia dini harus ditingkatkan, sebab kompetensi yang baik dapat meningkatan mutu pembelajaran dan sekaligus kepercayaan diri para guru PAUD. Mayasari (2014) telah melakukan penelitian terhadap para guru Raudhatul Atfhal (RA) yang menjadi peserta Orientasi Pembinaan Usia Dini Angkatan I se-Sulawesi Tenggara Tahun 2012. Hasil penelitiannya menunjukkan, guru yang tingkat pemahamannya tinggi tentang tumbuh kembang juga memiliki self efficacy mengajar yang tinggi, bahkan sangat tinggi. Artinya, ketika seorang guru memiliki pengetahuan atau kompetensi yang baik, maka kepercayaan dirinya (self efficacy) juga 
meningkat.

Peningakatan kompetensi di bidang pengembangan keterampilan motorik kasar anak usia dini bagi guru PAUD di Indonesia harus mempertimbangkan latar belakang kesarjanaan para guru, sebab tiga jenis kesarjanaan yang dapat dijadikan sebagai syarat guru PAUD memperoleh bekal pengetahuan yang berbeda tentang pengembangan keterampilan motorik kasar. Sarjana PAUD di Indonesia mendapatkan bekal pengetahuan yang terkait dengan pengembangan keterampilan motorik kasar anak usia dini sebanyak 3-12 SKS (lihat tabel 1). Sebaliknya, sarjana kependidikan lainnya yang relevan dan/atau sarjana psikologi tidak mendapatkan pengetahuan tersebut; kalaupun mendapatkan hanya teori saja dan tidak mempunyai pengalaman praktik (Unnes, 2016; Universitas Terbuka, 2015).

Peningkatan kompetensi program studi S1 PAUD

Pembahasan tentang kompetensi sebelumnya telah menyimpulkan, pembekalan tentang pengembangan keterampilan motorik anak usia dini pada program studi S1 PAUD telah memadai dilihat dari struktur kurikulumnya. Namun demikian, perlu dikaji lebih lanjut mengenai cakupan dan kedalaman materi setiap mata kuliah, termasuk di dalamnya pengalaman praktik para mahasiswa. Misalnya, sudah atau belum seluruh pola gerak diajarkan kepada para mahasiswa, sebab dalam gerakan tubuh manusia terdapat berbagai pola gerak seperti pola serasi, menyilang, dua sisi yang sama gerak bersama, dua sisi berbeda gerak bersama, dan sebagainya, serta gerak perseptual, metode mengurai gerak, dan sebagainya. Cakupan dan kedalaman materi setiap mata kuliah ini yang belum diungkap di dalam kajian ini dan sekaligus merupakan keterbatasan kajian.

Terlepas dari belum terungkapnya cakupan dan kedalaman materi di atas, satu hal yang perlu dipikirkan dan ditindaklanjuti bahwa untuk peningkatan dan pemerataan kompetensi calon guru PAUD perlu adanya pembenahan struktur kurikulum yang terkait dengan pengembangan keterampilan motorik kasar anak usia dini pada Program Studi S1 PAUD. Penyeragaman struktur kurikulum, terutama mata kuliah yang terkait dengan pengembangan keterampilan motorik kasar anak usia dini harus dilakukan. Peraturan Pemerintah Nomor 17 Tahun 2010 tentang Pengelolaan dan Penyelenggaraan Pendidikan, Pasal 97 ayat (2) yang memberikan wewenang kepada perguruan tinggi untuk menyusun kurikulum sendiri, perlu direvisi atau setidaknya dibuatkan peraturan menteri agar terjadi keseragaman struktur kurikulum antar-Pogram Studi S1 PAUD di Indonesia.

Mengenai intensitas pembelajaran pengembangan keterampilan motorik kasar anak usia dini, kita bisa mencontoh Pemerintah Swedia. Mereka melakukan pendekatan persiapan guru anak usia dini secara efektif untuk menginduksi guru sebelum terjun ke lapangan Dalam pembelajarannya dilakukan latihan praktik, observasi, dan refleksi antara guru pra-layanan dan guru pembimbing (Johansson \& Sandberg, 2011). Mahasiswa atau calon sarjana program studi PAUD di Indiana University juga mendapatkan bekal pengetahuan tentang pengembangan motorik kasar anak usia dini melalui mata kuliah Physical Science through Inquiry sebanyak 3 SKS (Indiana University, 2014); demikian juga mahasiswa program studi PAUD di Texas A\&M University-Commerce, mereka juga mendapatkan bekal pengetahuan yang serupa melalui mata kuliah Physical Education, Health and Nutrition (Texas A\&M University-Commerce, 2016).

Dari uraian di atas dapat disimpulkan bahwa meningkatkan kompetensi calon guru PAUD melalui program studi S1 PAUD dapat diawali dengan merevisi Peraturan Pemerintah Nomor 17 Tahun 2010 tentang Pengelolaan dan Penyelenggaraan Pendidikan Pasal 97 ayat (2), agar terjadi keseragaman struktur kurikulum antarpenyelenggara program studi S1 PAUD, terutama mata kuliah yang terkait dengan pengembangan keterampilan motorik kasar anak usia dini. Pendalaman materi perlu dilakukan melalui praktik di lapangan dalam bentuk latihan praktis, observasi, dan refleksi antara guru calon mahasiswa dengan guru pembimbing.

\section{Peningkatan kompetensi program studi S1 pendidikan lain yang relevan}

Pengertian "S1 kependidikan lain yang relevan" di dalam syarat kualifikasi guru PAUD dapat menimbulkan penafsiran yang berbeda, dan ketika diartikan sebagai sarjana dari Program Studi PGSD, BK, PLPB, dan PLS, tidak satupun dari program studi tersebut yang memberikan pembekalan tentang pengembangan keterampilan motorik kasar anak usia dini secara memadai. Jika dikaitkan dengan pengembangan keterampilan motorik kasar anak usia dini maka penafsiran yang tepat terhadap pengertian " $\mathrm{S} 1$ pendidikan 
lain yang relevan"adalah pendidikan jasmani kesehatan dan rekreasi (PJKR), sebab Program Studi S1 PJKR memiliki sedikit kekurangan dalam hal pengembangan keterampilan motorik kasar anak usia dini, yaitu belum mendapatkan pengetahuan tentang pembelajaran anak usia dini. Hal ini akan berbeda, jika pengertian tersebut dimaknai sebagai PGSD, BK, PLPB, dan PLS. Banyak hal harus dipersiapkan dan ditambahkan.

Berdasarkan uraian sebelumnya, ketentuan tentang 'kependidikan lain yang relevan' sebaiknya tidak perlu dicantumkan sebagai syarat kualifikasi akademik guru PAUD dan cukup S1 PAUD yang menjadi syarat kualifikasi. Kalaupun ketentuan tersebut tetap diberlakukan, maka PJKR merupakan program studi yang paling tepat, sebab peningkatan kompetensinya lebih mudah. Hanya dengan menambahkan pengetahuan tentang pembelajaran anak usia dini pada Program Studi S1 PJKR. Dengan cara yang demikian, sarjana PJKR lebih layak menjadi guru PAUD baik dalam pembelajaran secara umum maupun dalam pengembangan keterampilan motorik kasar.

\section{Peningkatan kompetensi program studi S1 Psikologi}

Bekal pengetahuan tentang anak usia dini, terutama terkait dengan pertumbuhan dan perkembangan anak sudah banyak diberikan oleh Program S1 Psikologi, sehingga para guru PAUD yang berlatar belakang pendidikan S1 psikologi telah memiliki banyak pengetahuan tentang tumbuh-kembang anak. Namun demikian, upaya peningkatan kompetensi mereka dalam pengembangan keterampilan motorik kasar anak usia dini tidak mudah, sebab untuk dapat mengajarkan keterampilan motorik kasar selain harus memahami teori pengembangan gerak juga harus mampu melakukan gerak ketika akan memberikan contoh kepada anak. Aktivitas kedua inilah yang menjadikan tidak mudah dalam peningkatan kompetensi calon guru PAUD yang dimulai Progran Studi S1 Psikologi.

Langkah yang dapat ditempuh agar sarjana psikologi memiliki kompetensi yang memadai dalam pengembangan keterampilan motorik kasar anak usia dini adalah dengan menawarkan program minor pendidikan anak usia dini di Program Studi S1 Psikologi. Selanjutnya, di dalam program minor tersebut diajarkan mata kuliah tentang pengembangan keterampilan motorik kasar anak usia dini. Program studi S1 Psikologi Universitas Mercu Buana Yogyakarta telah melakukan upaya yang mendekati pemikiran ini. Mahasiswa mendapatkan mata kuliah metode pembelajaran PAUD yang bobotnya 2 SKS (http://fpsi.mercubuana-yogya. ac.id/Kurikulum.php, diunduh 12 November 2016). Pemikiran tentang program minor ini sangat mungkin dilakukan, sebab Kolokium Psikologi Indonesia telah menetapkan, salah satu kompetensi sarjana psikologi adalah dapat bekerja sebagai pendidik di bidang pendidikan anak usia dini (Kolokium Psikologi Indonesia, 2010). Tentunya, sarjana psikologi yang menjadi guru PAUD juga harus memiliki kompetensi dalam pengembangan keterampilan motorik kasar anak usia dini.

\section{PENUTUP}

\section{Kesimpulan}

Kompetensi guru PAUD dalam pengembangan keterampilan motorik kasar anak usia dini

Guru PAUD yang mempunyai kualifikasi akademik S1 PAUD telah mendapat bekal yang cukup tentang pengembangan keterampilan motorik kasar anak usia dini dilihat dari struktur kurikulum yang ada pada program studi S1 PAUD, sehingga dapat dinyatakan memiliki kompetensi yang memadai dalam bidang tersebut. Namun demikian, jenis dan bobot mata kuliah yang terkait dengan pengembangan keterampilan motorik anak usia dini tidak selalu sama antar program studi S1 PAUD sehingga terjadi perbedaan kompetensi antar lulusan.

Guru PAUD yang mempunyai kualifikasi akademik $\mathrm{S} 1$ pendidikan lain yang relevan, seperti PGSD, BK, PLB, dan PLS tidak mendapatkan bekal yang cukup tentang pengembangan keterampilan motorik kasar anak usia dini dilihat dari struktur kurikulum pada program studi tersebut, sehingga kompetensi dalam bidang tersebut juga belum memadai. Selain itu, para sarjana jenis kependidkan lain yang relevan ini juga sangat minim mendapatkan bekal pengetahuan tentang pembelajaran anak usa dini.

Guru PAUD yang mempunyai kualifikasi akademik S1 psikologi telah mendapatkan 
bekal pengetahuan teori yang cukup tentang perkembangan motorik anak usia dini, namun kurang memiliki pengetahuan praktis dan praktik pengembangan keterampilan motorik kasar anak usia dini, sehingga kompetensinya belum memadai dalam bidang tersebut.

Upaya peningkatan kompetensi guru PAUD dalam pengembangan keterampilan motorik kasar anak usia dini.

Peningkatan kompetensi guru PAUD tidak dapat dipisahkan dari peningkatan kualifikasi akademik, sebab kualifikasi akademik yang tinggi dapat meningkatan kompetensi. Masih ada 180. 791 atau 59.83 persen guru PAUD yang belum memenuhi kualifkasi akademik/sarjana pada tahun 2013/2014, dan dari jumlah tersebut sebanyak 154.812 yang berstatus sebagai guru tidak tetap, sehingga secara finansial kecil kemungkinannya untuk melanjukan ke jenjang sarjana atas biaya sendiri.

Peningkatan kompetensi melalui program studi S1 PAUD cukup dilakukan dengan melakukan penyeragaman jenis dan bobot mata kuliah yang terkait dengan pengembangan keterampilan anak usia dini pada i seluruh program studi S1 PAUD di Indonesia, sebab masalah utamanya hanya pada tingginya variasi perbedaan jenis dan bobot mata kuliah tersebut.

Peningkatan kompetensi melalui program studi S1 kependidikan lain yang relevan perlu upaya yang besar dan cukup sulit, sebab pada program studi tersebut belum memberikan mata kuliah tetang pembelajaran anak usia dini dan juga tentang pengembangan keterampilan motorik kasar anak usia dini. Peningkatan kompetensi menjadi lebih mudah jika pengertian kependidikan lain yang relevan dimaknai atau diganti dengan PJKR, sebab pada program studi S1 PJKR telah diberikan mata kuliah tentang pengembangan keterampilan motorik secara lengkap; dengan hanya menambahkan mata kuliah tentang pembelajaran anak usia dini, para lulusan S1 PJKR sudah memenuhi kompetensi.

Peningkatan kompetensi melalui program studi S1 psikologi memerlukan upaya yang lebih mudah dan ringan, sebab pada program studi tersebut telah diberikan mata kuliah tentang tumbuh kembang fisik dan motorik anak usia dini. Penambahan mata kuliah yang terkait dengan pengembangan keterampilan motorik kasar anak usia dini dengan memperbanyak praktik sudah dapat mencapai kompetensi yang memadai.

\section{Saran}

Melakukan revisi terhadap Peraturan Pemerintah Nomor 17 Tahun 2010 tentang Pengelolaan dan Penyelenggaraan Pendidikan Pasal 97 ayat (2) yang target utamanya melakukan penyeragaman jenis dan bobot mata kuliah yang terkait dengan pengembangan motorik kasar anak usia dini di LPTK penyelenggara program studi S1 PAUD di seluruh Indonesia. Tanpa merevisi isi dari ayat tersebut akan sulit untuk menyeragamkan jenis dan bobot mata kuliah yang terkait dengan pengembangan keterampilan motorik kasar, sebab ayat tersebut memberi wewenang kepada setiap perguruan tinggi untuk menyusun kurikulum sendiri.

Penyediaan beasiswa oleh pemerintah kepada guru PAUD yang berstatus sebagai guru tidak tetap untuk melanjutkan studi ke jenjang S1 PAUD, sebab para guru ini secara finansial sangat kecil kemungkinannya untuk melanjutkan studi atas biaya sendiri.

Melakukan revisi terhadap Permendikbud Nomor 137 Pasal 25, ayat (1) butir b, yaitu mengganti ketentuan "S1 kependidikan lain yang relevan", dengan "S1 PJKR", sebab S1 PJKR merupakan program studi yang telah memberikan mata kuliah tentang pengembangan keterampilan motorik kasar secara lengkap, baik dalam bentuk teori maupun praktik. Kompetensi yang memadai dalam pengembangan keterampilan motorik kasar anak usia dini akan dicapai oleh para mahasiswa hanya dengan menambahkan mata kuliah tentang pembelajaran anak usia dini.

Menyediakan progam minor pendidikan anak usia dini pada program studi S1 psikologi bagi mahasiswa yang berminat menjadi guru PAUD, dan pada program minor tersebut diberikan mata kuliah tentang pengembangan keterampilan motorik kasar anak usia dini dengan memperbanyak praktik. Penawaran program minor ini direkomendasikan mengingat program studi S1 psikologi telah banyak memberikan mata kuliah tentang tumbuh kembang anak, dan hanya kurang dalam praktik pengembangan keterampilan motorik kasar bagi anak usia dini. 


\section{DAFTAR PUSTAKA}

Andal, C. (2016). China sport: Soccer kindergarten books published nation wide in China. Diakses dari http://en.yibada. com/articles/100485/20160118/chinasports-soccerkindergarten-books-publishednationwide.htm\#ixzz4J8OXKX7k

Barati, H., et.al. (2012).The effect of social skills training on socialization skills in children with down syndrome. Iranian Rehabilitation Journal. 2012; 10(15):35-38.

Department for Education. (2013). Early learning and childcare: Guide for providers. Diakses dari https://www.gov.uk/ topic/schools-collegeschildrens-services/early-years

Dortaj, F., \& Asemi, S. (2012). The effect of motor program selected on cognitive-motor and achievement in student with slow learning on second grade. Journal of School Psychology, 4(1), 39-56.

Ding, D, et al. (2016). The economic burden of physical inactivity: a global analysis of major non-communicable diseases." The Lancet 388.10051: 1311-1324.

Fitriya, S.I.A. (2014). Perbedaan tingkat pendidikan guru TK terhadap kualitas kegiatan belajar mengajar di TK di Kecamatan Tawangharjo, Kabupaten Grobogan. Naskah Publikasi. Skripsi. FKIP Universitas Muhammadiyah Surakarta.

Indiana University Bloomington. (2016). Undergraduate, programs early childhood education. Diakses dari http://education. indiana.edu/undergraduate/programs/earlychildhood.html

Johnstone, J.A. \& Ramon, M. (2011). Perceptualmotor activities for children: An evidencebased guide to building physical and cognitive skills1st edition. Champaign, IL: Human Kinetics.

Johansson, I., \& Sandberg, A. (2011). Learning and knowledge development in preschool teacher education and practicum. Early Childhood Development and Care, iFirst edition, 1-14.

Kemdikbud. PDSP. Indonesia. (2014). Statistik pendidikan anak usia dini 2013/2014. Jakarta: Setjen, Kemdikbud.

Kemendikbud. (2013). Deskripsi umum dan learning outcome 12 Prodi LPTK. Direktorat
Pembelajaran dan Kemahasiswaan, Direktorat Jenderal Pendidikan Tinggi, Bekerjasama dengan Asosiasi Lembaga Pendidikan Tinggi Tenaga Kependidikan Indonesia (ALPTKI) 2013.

Kolokium Psikologi Indonesia. (2010). Kompetensi pendidikan bidang psikologi. Diakses dari http://ap2tpi.or.id/index. php?option=com_k2 $\&$ view=itemlist\&layout=category\&task.

Lupu, E., (2010). Motion activities and their importance in the physical and intellectual development of the institutionalized children. Journal Procedia Social and Behavioral Sciences. 5: 2140-2145.

Lupu, E. (2011). Study regarding the impact of motion games in the intellectual motoric development of preschool children. Journal. ProcediaSocial and Behavioral Sciences. 30:1209-14.

Marlina, N. S. (2011). Kemampuan guru TK dalam mengajar gerak anak pada Taman KanakKanak di Matraman Jakarta-Timur dalam upaya peningkatan kebugaran jasmani pada anak usia dini. Jurnal Olahraga Prestasi. 7(1), Januari 2011.

Mayasari, R. (2014). Gambaran tingkat pengetahuan tumbuh kembang anak, self efficacy mengajar dan kreativitas guru raudhatul atfhal di Sulawesi Tenggara. Jurnal Al Izzah. 9(2), November 2014.

Mercubuana. (2016). Kurikulum. Diakses dari http:// fpsi.mercubuana-yogya.ac.id/Kurikulum.php

Norris, D. (2010). Raising the educational requirements for teachers in infant toddler classrooms: Implications for institutions of higher education. Journal of Early Childhood Teacher Education, 31, 146-158.

Peraturan Pemerintah Nomor 17 Tahun 2010 tentang Pengelolaan dan Penyelenggaraan Pendidikan.

Permatasari, F.D. (2011). Hubungan stimulasi dini dengan perkembangan motorik kasar anak usia toddler di Teman Sejati Sari Husada Kotabaru Yogyakarta. Skripsi Naskah Publikasi. Sekolah Tinggi IImu Kesehatan Aisyiyah Yogyarta.

Permendikbud Nomor 137 tahun 2014 tentang Standar Nasional Pendidikan Anak Usia Dini. Petrovici, C. \& Masari, A.G. (2014a). Content analysis 
of syllabus for students of kindergarten and primary school pedagogy according to the professional competences. Journal Procedia - Social and Behavioral Sciences 146 ( 2014 ) 28 - 33. doi:10.1016/j.sbspro.2014.08.082

Petrovici C. \& Masari, A.G. (2014b). Aligning the academic teacher training curriculum for preschool and primary school education to the requirements of the RNCIS. Journal Procedia Social and Behavioral Sciences, Volume 142, 14 August 2014, 731-737

Pienaar A. E., et.al. (2011). The effect of a kinderkinetics programm on components of children's perceptual-motor and cognitive functioning. Journal for Research in Sport, Physical Education and Recreation. 2011; 33 (3), 113-128.

Puspitarini, A. (2015). Meningkatkan kemampuan fisik motorik melalui implementasi tari kupukupu menggunakan metode gerak dan lagu pada anak kelompok B PAUD Tunas Bangsa Rejotangan Kabupaten Tulungagung. Skripsi. Fakultas Keguruan dan IImu Pendidikan Universitas Nusantara PGRI Kediri.

New Jersey Department of Education. (2014). Preschool teaching and learning standards. Diakses dari www.nj.gov/education/ece/guide/ standards.pdf.

Sajedi, F. \& Barati H. (2014). The effect of perceptual motor training on motor skills of preschool children. Iranian Rehabilitation Journal. 12(19), 14-17.

Sheridan, S. (2009). Discerning pedagogical quality in preschool. Scandinavian Journal of Educational Research. 53(3), 245-261.

Texas A\&M University-Commerce. (2016). Early childhood curriculum course syllabus: Spring 2016. Diakses dari www.tamuc.edu/
academics/cvSyllabi/syllab i/201720/20009. pdf

Tucker P. (2008). The physical activity levels of preschool-aged children: A systematic review. Early Childhood Research Quarterly. 23(4), 547-58.

Universitas Terbuka. (2015). Katalog program penjas Universitas Terbuka 2015. Diakses dari www. ut.ac.id/images/katalog/.../Katalog_Program_ Pendas_UT_2015.

UNNES. (2016). International curriculum: Daftar mata kuliah kurikulum internasional Jurusan PGPAUD Unnes. Diakses dari http://paud. unnes.ac.id/index.php/kurikulum-internasi onal/Copyright $\odot 2016$.

Universitas Padjadjaran. (2012). Pedoman penyelenggaraan pendidikan, Fakultas Psikologi, Universitas Padjadjaran Tahun 2012-2013.

Utami, N. (2014). Upaya meningkatkan kemampuan motorik kasar berbasis soft skill melalui pembelajaran senam fantasi pada siswa kelompokA RA Muslimat NU. Skripsi. Fakultas IImu Tarbiyah dan Keguruan. Universitas Islam negeri Sunan Kalijaga, Yogyakarta.

Veldman SLC, Jones RA, Okely AD. (2016). Efficacy of gross motor skill interventions in young children: an updated systematic review. BMJ Open Sport Exerc Med 2016;2: e000067. doi:10.1136/bmjsem-2015-000067.

Widodo. (2015). Identifikasi kesiapan belajar motorik anak usia dini (4-5 tahun). Yogyakarta: Azzagrafika.

Yudanto. (2007). Stimulasi gerak dasar siswa sekolah dasar kelas bawah. Jurnal Pendidikan Jasmani Indonesia, 4(2), Nopember 2007. FIK UNY. 